\title{
Making love, making empire
}

On 19 April 1899 a troupe of South African 'tribal' groups landed at Southampton docks on the South Coast of England. Later that month they were due to perform a central role in the Earl's Court exhibition Savage South Africa. Local reports claimed that 'among the effects were over 200 natives of South African tribes, a number of Boer families, representatives of the mounted police, and a number of animals' (Shephard 1986: 97). Early film footage, archived by the Colonial Film Project, shows the apparent moment when the groups disembarked. One reel shows a group of 'Zulu' men, clad in 'tribal dress' and clutching spears, performing a choreographed dance for the camera and bystanders (Colonial Film Project 2018). The film shows the group striking an imposing presence, with the merchant docks foggy in the background. Thirty seconds into the reel, a white man in a top hat and dark overcoat stumbles into the frame, stares at the troupe and then leads some of the men further forward towards the camera.

This moment captures a significant imperial encounter. It represents the overlapping of colonial technologies - the camera lens, the white man's instruction, the coherence of the performance - all situated within the wider context of the imperial exhibition (see chapter 7 for more on this, and also Mitchell 2000: 7-13). The arrival of Savage South Africa in London tells us how empire was constantly remade not only in 'overseas' colonies but also in encounters within the urban metropole. London is constituted here as part of 'imperial terrain' (Burton 1998: 5 ) - the site of rebounding and contingent colonising processes (Lowe 2015). The event also stands as a particular encounter in the racialised 
and sexualised logics of colonialism. It stands, I argue, as an example of the way that mobility, intimacy and claims to family played a central role in both energising and organising colonial rule.

After the opening of the exhibit, newspaper stories circulated regarding the effect of the presence of the 'savages' in London. Exoticised and eroticised accounts of 'savage' behaviour spread as far as the Los Angelesbased Pall Mall paper. White women, it was said, were seen disappearing into the tribal tents which constituted the 'Kaffir kraal' section of the exhibition to partake in the 'vilest orgies'. The Daily Mail described how 'women of gentle birth, crowd round the near-naked blacks, give them money, shake hands with them, and even go down on their hands and knees in order that they may further investigate the interior of the overcrowded huts' (quoted in Shephard 1986: 101).

Alongside familiar representations of hypersexualised black masculinity (or the 'black peril'), complaints were raised in South Africa on 'racial grounds' (Colonial Film Project 2018) that these 'well-policed natives' posed a significant threat. This was framed as a threat not only to British society but also imperial rule more broadly. The South African press feared that 'nothing but vice in a white skin would satisfy [the 'savages'] thereafter' (Shephard 1986: 97). The exhibition threatened to trouble the sexual demarcations of the 'colour line'. By August 1899 the 'Kaffir kraal' was officially closed to women.

Whilst the press initially raised concerns over interracial sex and the spectre of the 'black peril' (which I return to below), focus began to fall on the coupling and engagement of 'Prince' Lobengula of Matabeleland, with a local white woman, Miss Florence 'Kitty' Jewel. The couple had met in 1898 in Bloemfontein, South Africa, and continued their romance on Lobengula's arrival in London with the exhibition. The Galveston Daily News concluded the grave news that 'this little band of savages has brought home to the English people for the first time the seriousness of mixed marriages' (Colonial Film Project 2018). The prospected marriage revealed broader concerns about 'miscegenation', which the Spectator argued 'has long been regarded by the Anglo-Saxon race as a curse against civilisation' (quoted in Shepard 1986: 101). 
Stoler (2002) reminds us how managing intimacy was central to the power relations of empire. Appropriate behaviours, sexual conduct, proximity and touching all worked as sites of struggle over race, gender, class. As developed in the case of the 'savages' of South Africa, orientalist imaginaries of feverish sexuality, immorality and virility conditioned both the racialisation of colonised men but also the parameters over the acceptable conduct of white women. We can read the crisis surrounding the exhibition as a constellation of fears over miscegenation and racialised 'others' penetrating the white (national) body (Yuval-Davis 1997). But this misses out on the complex ways that claims to family were already bound to the architecture of imperialism and with it the regulation of movement.

It is important to recognise how the fear of interracial intimacy described here was specifically translated into familial and imperial terms. What worried commentators more than interracial sex per se was the promise of interracial marriage proposed by 'Prince' Lobengula and Miss Jewell. Such a union was viewed as 'degrading' the moral and racial claim to white superiority, as well as practices of inheritance and patriarchal rule that structured empire. It equally focused on the impossibility of non-European family and the deviancy of uncivilised kinship practices. The press worried what would happen to Miss Jewell if she wed with this 'dusky savage' (Shepard 1986: 99). Lobengula and Jewell's marriage was not so much presented here as a threat to national integrity as to white colonial power - a power that was 'dissipated by daily familiar intercourses at Earl's Court' (Shepard 1986: 101). The fear was that if such unions were given the blessing of the church and state in the metropole, this promised to weaken the racialised-sexualised power of colonial administration, and weaken violent practices that apparently held native passions at bay all over the British Empire.

In this context, we need to consider how the arrival of 'savages' in London was constituted as a problem of movement across empire - how the movement of certain racialised bodies to the metropole challenged apparently stabilised hierarchies arranged around the (white) family. The closing of the exhibition to women thus became a key governmental 
move to stabilise fluid boundaries and reimpose a dominant set of ideas around racial intimacy, as did attempts by the management of the exhibition, the local vicar and the Chancellor of the Diocese of London to stop Lobengula and Jewell's wedding. These strategies acted to contain threatening mobility, bodies and intimacy. They were thus acts of bordering. To recognise this is to begin to flesh out how 'family' energised forms of imperial rule, including the regulation of movement.

\section{Making empire}

This brief detour through the Savage South Africa affair introduces several themes explored in this chapter, which examines how 'family' and 'borders' were entangled and made across the British Empire. Whilst intersecting analyses of race, sexuality and gender which focus on 'perversity' or 'feminisation' are useful tools for critiquing how colonialism was arranged through intimacy, I want to stress how heteronormative family was central to empire-making across metroimperial space (Mendoza 2016). As I outline above, it is the family that energises the spectacle of Savage South Africa - the fear of coupledom, reproduction and domesticity. Bearing in mind the relationship between family, domestication and borders I sketched out in the last chapter, I turn in this chapter in more detail to the political work family performed in British imperial and colonial projects (and then into the present). I examine how family worked and still works to energise colonial domesticating power, in terms of making decisions over what bodies and populations are protected, fostered and sustained, and who is abandoned, who is deemed dangerous and who can be stamped out.

Central to questions of life and death under colonial rule were questions of mobility. Sustaining and expanding the British Empire relied on the emergence of borders as a way of managing racialised populations, extracting profit and labour, and with this, forms of sociosexual relations, intimacy and kinship. This was not only about controlling movement but at some moments enforcing movement, at other times 
facilitating sedentarism and the active promotion of heterosexual, single-household bourgeois domesticity as the template of 'civilisation' (Rifkin 2015). I extend the argument in this chapter, that 'family' was not only useful as an ideological tool of moral and civilisational judgement (which it was) but also a technology which shaped who could move where, with who and under what conditions.

Drawing on the position I briefly introduced with the example of Savage South Africa, I make a further contribution to debates on borders. I propose, against so much of the common sense in migration studies, that bordering practices are imperial in orientation, not national (also see Lake and Reynolds 2008; Bhambra 2017b). Bordering, I argue, emerged not to manage national populations but to manage imperial movement (see El-Enany 2020). Or, to be more specific, it was racialised mobility that was of concern to modern states (Mongia 2018). Disparate bordering practices increased in scale from the eighteenth century to regulate colonised populations who needed to be moved, resettled and enclosed in line with the evolving logic and needs of imperial racialised capitalism, and a dominant liberal heteropatriarchal order which fetishised the European nuclear family. What I propose in this chapter is that the birth of what we come to call immigration law in Britain was already conceived through both an imperial vision of the world and by drawing upon key practices of colonial rule - that is, the practical tools, strategies and knowledge of racialised governance. Immigration law is the institutionalisation of older forms of bordering and the innovation and expansion of borders by postcolonial states. It has thus become a key site through which colonial mandated ideas of family are resuscitated and reimagined. This chapter thus sets the scene for the more contemporary analysis that follows it. ${ }^{1}$

The chapter is split into three parts. Off the back of the Savage South Africa case, the first section traces the way that 'family' functioned across different sites of the British Empire: from a means of distributing racial bloodline and inheritance, to the organisation of violent suppression, to the management of movement. This explores how slavery was organised around the absence of family and how black communities 
were equally seen as a threat to the white imperial order in the midnineteenth century, particularly with the Morant Bay revolution in Jamaica. I take up the emergence of bordering practices here and suggest that regulating the movement of indentured labourers after the abolition of slavery became a prime concern of British authorities and settler states alike. This ultimately led to the innovation of bordering and nascent forms of immigration control in the late 1900s.

The second section of the chapter focuses on the developmental promise of 'marriage' and 'family'. Anthropology was central in drawing up global 'family taxonomies' which hierarchised colonised populations based on kinship structures and ideas of perversions. As well as showing how colonial states 'developed' populations through the family, I reveal how ideas around what or who could be family became increasingly important in emergent immigration regimes in white settler states.

The final section brings the discussion full circle by showing how imperial bordering circulated through the metropole. This explores the emergence of British immigration law, which I demonstrate was born out of the push to manage racialised mobility, orientated as this was around the colour line of empire. Whilst bordering practices were developed to protect and sustain the white (or in British imperial language, 'AngloSaxon') family, they were also experimented with to surveil the intimate relations of citizens of colour. I end by considering the significance of the British Nationality Act 1981, which ended the imperial definition of British citizenship and bound it to bloodline and kinship.

\section{Blood, inheritance and the family}

If the incident of imperial intimacies I began this chapter with raises the question of inheritance and bloodline in relation to British imperial rule, then this is only because this was key to how racial order was constituted across the Empire (Neti 2014). As Robbie Shilliam (2018) has demonstrated, British common law (from the sixteenth century) was organised around patriarchal descent. However, commercial law 
dominated in colonies. Whilst colonised people were seen as anthropologically bereft of proper family relations, they were equally denied methods of inheritance that were key to legal authority in Britain and the reproduction of social relations. Slaves were denied the right to family law across the British Empire - throughout American colonies, the West Indies and then under American settler colonialism after independence (Patterson 1982: 56-57). As Burnham (1987) argues, under the extensive plantation system that emerged in the eighteenth century, slaves could reproduce but could never be parents in the legally recognised sense. Instead, slaves were rendered commercial property and inherited slave status through their mother (i.e. the mother's master owned her children). Here slavery functioned as an inherited commercial bloodline rather than as a unit of kinship.

Tellingly, from the late eighteenth century, abolitionist critiques of slavery focused on how commercial law and slavery denied patriarchy lineage and posed an 'internal' danger to British moral authority and the 'family of man' that liberal empire was supposed to cultivate (Shilliam 2018: 35). To abolitionists such as William Burke, slavery was not necessarily dehumanising or racist. It instead threatened the proper gendered and sexualised relations of Christian marriage, family and patrilineal inheritance that were so central to British order (Shilliam 2018: 17). The promise of abolition in 1834 rested on the idea that newly freed slaves could be contained and governed by European codes of domesticity and labour in order to rid themselves of the essence of slavery (a point I return to below).

If bloodline organised the structure of chattel slavery and the dehumanisation of enslaved Africans (cutting them out of family law and the possibility of kinship), filial blood also arranged ideas of 'racial types' under British law. Satnam Virdee (2019: 12) describes this legal evacuation of black subjects from family as central to the early foundations of racial categorisation in American colonies from 1607. Not only were slaves and black subjects defined by descent but colonial law punished 'fornications' between slaves, black labourers and white colonialists, with the heaviest measures targeted at relations between 
white women and men of African descent (Virdee 2019: 12). As Colin Dayan (2011) demonstrates, being categorised closer to 'white' or 'black' was done on parental genealogy (a template that would be copied and refined in white supremacist regimes from the American South to South Africa). The transmission of 'black blood' was viewed as a 'stain' (Dayan 2011: 49). In turn, this decided whether a subject could be born into slavery or could inherit 'freedom'. Under West Indian law, for example, being classed as only having one-eighth 'black blood' made someone legally white and thus 'free' (Dayan 2011: 52). Just as subjects were born into slavery, the children of mixed unions (often free or white men and slave women) could inherit freedom from their father. In fact, the transmission of freedom grew so worrying that in the late eighteenth century in Jamaica, laws were brought in restricting 'mixed' or 'coloured' children from inheriting wealth (Patterson 1982: 146). Under imperial hierarchies of 'humanity', personhood was thus gained or eviscerated through a patriarchal connection to whiteness.

If imperial law shaped both who could be a family and in turn who could be fully human, this worked in relation to how imperial subjects were recognised as familial. Whilst populations within all British territories were conceived of as 'subjects of the Crown' this obscured how personhood was stratified in relation to whiteness, with black slaves at the bottom of this hierarchy. After the Indian War of Independence in 1857 , colonial projects were increasingly conceived in terms of the protection and sustenance of an 'Anglo-Saxon family' (Metcalfe 1998; Shilliam 2018: 35-36). The task of colonial power in this period was directed at fostering this family through often-violent forms of capital accumulation and authoritarian government. This intensified already violent racial demarcations around a more explicit protection and fostering of capital interests in colonies and in further linking the metropole with white settler interests.

'Family' here functioned as more than a metaphor; it was an integral aspect of empire-making. Threats to family order could shape and justify how populations were governed. In 1865, black communities in Morant Bay, Jamaica, began an anti-colonial insurrection against the colonial 
settler authorities and local elites. The violent suppression of the revolution was later used to debate both liberal and conservative ideologies of empire in Britain (Hall 2002), but it equally revealed the stark realities of colonial-racial hierarchies and violence. In a letter to Edward Eyre (the governor of the colony), Major General Jackson (1865) outlined the visceral disgust he felt when witnessing 'black labourers' harassing a 'White Lady' during the uprising. Such a moral outcry, which replicated ideas of the sexualised 'black peril', was central to Jackson's justification for the extension of martial law and bloody repression over parts of the colony. It was 'extremely regrettable that the opportunity was not seized to set an example ... with a severe flogging, he argued (Jackson 1865).

The suppression of the Morant Bay insurrection by Eyre and his generals would become synonymous with the most violent excesses of colonial violence. Eyre attempted to justify the suspension of the law, the deployment of troops and the systematic murder of hundreds of black men and women and the burning of their homes as being necessary to save 'decency' and 'Anglo-Saxon' 'democratic rule' (also see Hall 2002). Eyre (1865) argued to the House of Assembly a week after Jackson's letter that the 'peasantry of Jamaica have nothing to complain of'; 'rebellion, arson, murder' were merely the products of an 'ignorant, uncivilised, excitable population' easily persuaded by 'anti-English rhetoric'. As demonstrated by these connections, intimate domestic order and the white woman's body were used to configure the dangers of black rebellion and 'mob rule' (Head 2017). Whilst 'family' provided an organising principle for categories of humanity and personhood, colonial power was also orientated towards acts of violent domestication and dehumanisation in order to protect the 'Anglo-Saxon' family (in Jackson's case embodied by the lone white woman).

\section{Borders and mobility}

One of the key features of Eyre's violent domestication of revolutionaries in Jamaica was the curbing of mobility of black communities who were 
rendered a permanent risk to white settlers under martial law (Hussain 1999; Head 2017). However, such 'emergency' tactics were hardly exceptional and instead indicative of a more long-standing push to regulate movement by colonial states, plantation owners and private companies alike. As I began describing in the last chapter, managing settler and colonial projects across the British Empire was constantly bound to the need to manage movement. The increasing capitalisation and centralisation of the English state in the seventeenth century was built on practices of enclosure and the promotion and restriction of (im)proper movement (Federici 2004; Papadopoulos et al. 2008). Equally, experiments to domesticate colonised populations relied heavily on experiments in bordering. Key to strategies of accumulation and the reproduction of labour across the British Empire was the push to discover and categorise disorderly movement - those 'out of place' and 'worthless'. As colonies were more tightly networked into the imperial economy, this bordering worked to the particular demands of racialised capitalism, which demanded often contradictory processes of settlement, containment and identification. As we shall see, this provided a continued site for ideas of inheritance and family to be sustained and reimagined.

Radhika Singha (2000) argues that the East India Company consolidated control over India in the eighteenth century primarily through the regulation of movement. This process necessitated experimentation in colonial government and the birth of many modern policing and border methods. The emergent colonial state began to intensify forms of sedentarism with the hope of controlling forms of 'risky' movement across the Indian subcontinent (see Sleeman 1839 as a key architect of this). Here pilgrim throngs, hunting bands, daciots and 'bandits', itinerant communities who travelled without sufficient scrutiny such as religious mendicants, prostitutes and slave traders, increasingly became subject to experiments in enclosure, containment and monitoring (also see Legg 2007). As Singha (2000: 152) highlights, administrators were particularly anxious about the apparent absence of visible social hierarchies and 'verified social antecedents' which allowed colonial subjects to 'conceal or misrepresent their true identity' whilst they moved. 
Authorities went to great lengths to capture moving bodies through innovations in policing tactics and the formation of modes of identity capture, categorisation and visual techniques. Browne (2015) argues that the formative modes of identity capture which were initially experimented with in plantation economies - slave ledgers and 'wanted' posters for escaped slaves - provided powerful forms of racial control and forms of proto-visual surveillance (see chapter 6 for more on this). We can see how emergent bordering practices such as these relied on producing stabilised identities that could be categorised, inscribed and made seemingly 'permanent', for example by physically marking risky bodies with tattoos, branding or finding 'unique' markers such as fingerprints, signatures and eventually DNA testing. This push to inscribe identity both on bodies and through the categorisation of mobility underpinned the development of passport technology (see Mongia 1999, or for a different account Torpey 2009).

\section{Managing indentured labour}

Bordering worked at key nodal points across both colonies and the metropole to allow some people to move freely and to restrain others (Mongia 2018: 56-85). The control of mobility was networked through the trade and movement of first slaves, then after abolition, indentured labour and convicts. ${ }^{2}$ Bordering practices emerged in the context of a variety of spaces, from cotton production in the West Indies and the spice plantations of South India, to English industrial cities and Australian penal colonies. Port inspections, medical examinations, censuses and enclosures during pilgrimages all sought to regulate movement around the dictates of the evolving forms of imperial capitalism and the promotion of the 'Anglo-Saxon' family. Whilst all subjects of the Crown were technically entitled to move across the British Empire, these flows were managed in line with anxiety around the permanent settlement of black and Asian labourers, and hierarchised principles of citizenship (see Harrington 2012; Nahaboo 2018). This was crystallised in the context 
of white settler immigration policy developed in the latter part of the nineteenth century.

Mobility was equally facilitated and restricted within colonial states with the opening up of new markets such as the tea plantation system in North India, facilitated through the Assam Labour and Registration Act 1901, or in the plantation system in Guyana. Indentured labourers, as with slaves before them, could never move freely into or out of the plantation (or the state) (Mohapatra 2004). Without a pass and the relevant identity documents they could be arrested, beaten and even deported. Whilst the management of mobility was organised through the use of vagrancy laws that emerged in England from the seventeenth century, these laws were invariably applied to colonies but with a renewed racialised function.

Regulating movement across the British Empire also necessitated experimenting with more systematic control than vagrancy laws provided. In 1875, for example, the Indian Ports Act was introduced to regulate the flow of indentured labourers out of ports such as Mumbai and Chennai. Further acts were brought in to manage the use of cheap labour in the plantations of the West Indies, on the South African railways and the expanding agricultural sector along the West Coast of America (Shah 2012; Madhwi 2015). Indentured labourers were used by colonial authorities to shore up the cheap supply of labour across the Empire (often as a replacement for slave labour after abolition). Indian subjects were often coerced into signing indentured contracts which meant being shipped to the far reaches of the British Empire in almost slave-like conditions (see Dei 2017: 26; for Chinese indentured labour see Lowe 2015). The management of these subjects created networks of borders from the state of origin through ports and transit points to the receiving territory. It is here, Radhika Mongia (2018) argues, that we need to view the move towards the state's monopolisation and centralisation of bordering and the creation of state-delimited borders.

State bordering took the form of different practices working across dispersed sites, from the administration of labour camps, the legal texts 
of indentured labour contracts and private shipping company manifests, to the regulation of tropical and venereal diseases, the criminalisation and expulsion of labourers after contracts expired and naturalisation practices (Gutiérrez Rodríguez 2018). Whilst this bordering went against the promise of imperial citizenship and the right to mobility, British authorities often worked in collusion with white settler states to curb and manage 'Asiatic' or 'coloured' mobility - such as the introduction of 'continuous journey' legislation, which restricted entry to Canada for passengers who did not travel on a direct route from their country of birth (for more on how this shaped migration from India see Shah 2012: 198, and Gutiérrez Rodríguez 2018: 22). This reveals how citizenship itself was structured around the ideal of white subjects belonging to Britain and European states (Nahaboo 2018). Bordering might have been increasingly monopolised by states but this was orientated around imperial concerns and the hierarchies of racialised mobility, which were still global rather than national.

Whilst the movement of 'productive' groups such as indentured labourers was viewed as necessary for the extraction of profit, borders worked to maintain the temporality of labourers and to manage sociosexual relations. In colonies from South Africa and Australia to the Caribbean and Pacific Island states such as Fiji, missionaries and colonial administrators alike continuously raised concerns about the immorality, promiscuity and litigious behaviour of indentured labourers. Reports increasingly circulated in the 1870s and again in the 1900s regarding the behaviour and moral conduct of Indian labourers in labour camps and on plantations (Emmer 1986). This led to the 1875 Indian Ports Act, and later the 1883 Indian Emigration Act and the monitoring of Indian ports of exit, as well as more localised forms of containment (i.e. the pass system, strict laws on movement, punishments for contravening contracts) that were intensified in colonies receiving indentured labour. As Mongia (2018) argues, whilst indentured labourers were viewed as more disciplined, it was those whose contracts had ended or who had escaped, or labourers who were non-indentured that authorities became concerned with. Labourers were presented as a particular type 
of masculinised-sexualised threat. The focus often fell on the imbalance of male over female indentured and non-indentured labourers on plantations and in camps. This was said to lead to an absence of 'stable' heterosexual unions and was explicitly linked with prostitution, promiscuity and homosexuality.

Here we find an early construction of the single male migrant who would later haunt the racialised imaginaries of nationalist discourse in white metropoles and settler societies throughout the twentieth and early twenty-first century. In a letter to Austin Chamberlain, the Secretary of State for India, Commander-in-Chief Beauchamp Duff (1915: 4) wrote that the 'moral conditions of the India Coolie lines in Fiji are indescribable', and that 'women emigrants are all too often living a life of immorality at the free disposition of their fellow recruits and even the subordinate managing staff'. In response, colonial administrators toyed with promoting the increased influx of Indian women to certain parts of the British Empire to actively promote forms of heterosexual family (Duff 1915: 5). Further laws stressed the need to forcibly repatriate and expel labourers on mass, following the Chinese exclusion laws in America (Tichenor 2002: 87-114). In South Africa suggestions were made for the drawing in of 'local' labour to protect the degrees of racial-sexual segregation that the colonial state was anxious to maintain. In Australia after 1905 any 'Asiatic' (even if a subject of the British Crown) found without the correct identity papers and proof of a contract could be subject to first imprisonment and then deportation. Such bordering was concerned with sustaining the global colour line arranged by the 'Anglo-Saxon' family by making mobile racialised-sexualised labour 'temporary', surveilled and disciplined, and ultimately expendable.

It is important to stress here how bordering was networked across metroimperial space and how claims to family energised bordering. Whilst 'family' was central to the organisation of racial order, bordering equally functioned to quell bodies deemed 'out of place' and disorderly, and to facilitate the mobility of those who possessed 'value' or who needed to be expelled (such as convicts, escaped slaves and non-indentured labourers). This worked across dispersed nodal points all over the 
British Empire and was managed by a host of authorities - medics, police, plantation owners, labour camp managers, shipping companies, port authorities. It involved the collusion of imperial as well as local authorities to manage and expand these sets of practices. Bordering practices attempted to regulate movement but this was networked not only through the extraction of profit but through appeals to forms of racialised-sexualised order and the challenge posed in the intimate and affective proximity of certain bodies. Whilst family and kinship could be violently denied in the terms of contracts of indenture, in the foundations of slavery or in the lives of 'black rebels', 'family' could emerge as a technique for taming 'strange intimacies' through moral correction, or in the planned and regulated promotion of Indian women to serve as potential wives for labourers. The sustaining and fostering of imperial inheritance relied on governmental and symbolic power of 'family' (Neti 2014). Not only does this reflect increasingly hardening views about the appropriate limits of interracial intimacy throughout the nineteenth century, but also the way that worthy/unworthy life was encoded around appeals to heteronormative domesticity.

This reflects an emergent and multivariate role for practices which regulated movement: borders could maintain European socio-sexual order (in this case the 'Anglo-Saxon' family). Borders could sustain production, the opening of markets and the extraction of profit. Borders could suppress, capture or expel the disorderly, the dangerous or deviant (such as black rebels or the non-indentured or escaped labourer). Borders could also work to promote the heterosexual family as a means of developing or controlling colonised populations. It is this last point that I return to in the next section.

\section{Family taxonomies, marriage and immigration control}

For the features of primitive life, we must look, not to tribes of kirghiz type, but to those of Central Africa, the wilds of America, the hills of India, and the islands of the Pacific; with some of whom we find marriage 
laws unknown, the family system undeveloped, and even the only acknowledged blood-relationship through the mother.

McLennan (1865: 8)

In a series of letters and reports sent to the Colonial Office in 1872, the Bishop of the African Mission in the colony of Mauritius pleaded with church authorities and British officials to intervene in the problems posed by freed and 'landed' slaves. In Mauritius the black community had steadily grown since abolition, and with the criminalisation of the slave trade, boats and their human cargo were often intercepted and landed on the islands of the Seychelles (Allen 2008). ${ }^{3}$ Equally, black indentured labourers were brought to the islands and used to force down wages. Significantly, Bishop William George Tozer (1872) described the population on the islands as being only 'freed in law' but not in essence or spirit: they were 'Heathen Negros' in a state of 'moral, physical and spiritual' arrested development, he argued. Despite the clear historical context of slavery and its abolition, which left these communities first reduced to chattel and then abandoned, the Civil Commissioner's inspection and report that accompanied his outcry focused on the domestic arrangements of the community (McGregor 1873). It placed attention on idleness, consumption of alcohol, and the half-naked and half-feral children running malnourished through encampments. It focused on the non-normative intimacies practised within the community and the condition of their huts that were 'dark with no ventilation' (McGregor 1873). 'Whilst mild and easily manageable', missionaries and civil authorities alike complained of the lack of spiritual uplift needed to 'elevate Africans into humanity' (Tozer 1872). Tellingly, one of the proposed practices of this 'uplift' was visualised in the absence of 'legitimate' (i.e. Christian) marriage.

Tellingly, domesticity and with it, 'marriage' were used as central tools in the management of black communities in Mauritius, as was true of large swathes of the British Empire. This provided several functions. The apparent absence of normative kinship (in this case Christian marriage and single-household monogamy) performed a racialising 
function to reveal the 'absences' of black and African people. The absence of proper domesticity was seen as reflective of their inability to throw off the 'essence of slavery' (Shilliam 2018: 55). Furthermore, the uptake of Christian marriage worked as a domesticating tool. Firstly, it was used to explain the precise spiritual and moral failure of their condition (such as idleness and the malnourishment of their children); secondly, Christian marriage was proposed as a solution to their predicament and a means of 'humanisation'. Domesticity here was viewed as a way of finally throwing off backwards kinship structures and 'developing' towards European modernity.

This reveals the varied role that marriage (and with it, normative claims to family) had in shaping and maintaining colonial order and with this imperial movement. Marriage categorised state-sanctioned forms of kinship, inheritance and access to citizenship. But in doing so it produced claims to civilisation and social development (Peterson 2014b). State investment in marriage was often carved out in a European setting alongside Christian authorities who committed to monogamous legal and spiritual forms of partnership and heterosexual family life (Cott 2000). In overseas colonies, Christian marriage served as a normative template against which other intimacies were judged (Neti 2014). Whilst liberals claimed that marriage was universal, this always worked to frame Christian marriage as an ideal against which other intimacies were viewed invariably as partial, deviant or threatening (Attorney General Dar Es Salaam 1951).

In this setting, anthropologists attempted to 'discover' whether local cultures practised 'marriage-like' rituals (Goody 1990) which could be sanctioned by the colonial state, thus conferring varying degrees of legitimacy and, with it, personhood. In this sense, they provided a taxonomy of family forms and perversions. Debates over the status of marriage became increasingly important in the early twentieth century as the scripting of who was or could be married was central to decisions over what constituted 'family' and with this an array of potential rights to British imperial citizenship and movement across the Empire. 


\section{Family as dehumanisation}

It is important to recognise the afterlife of slavery that drives the encounter in Mauritius and in the role of marriage and family more broadly. As noted earlier, claims to family worked to organise, rationalise and challenge slavery. As I noted in the last chapter, this means recognising, as Spillers (1987) argues, that dominant claims to family were central to the dispossession of Africans in reducing them to chattel. Here the organisation of gender relations and domesticity was not so much imposed upon African people through colonisation and enslavement but worked to eviscerate their personhood and claims to humanity (see Thomas 2007: 31). Spillers (1987) famously argues that, black (women) slaves were not so much gendered as ungendered. The categories of heteronormative family used to explain non-European people and their status as (in)human merely produced black women as a series of absences - (failed) women, (failed) mother, (failed) body.

It is important to see the (un)gendering that Spillers talks of as working alongside the creation of taxonomies of family and marriage across European empires. In many respects, the (un)gendering of black slaves is bound to and structures the hierarchy of who could be familial and thus properly human. It was this unfamilial 'essence of slavery' that black communities in Mauritius were unable to shake off. This anti-blackness connects to the way that nineteenth-century anthropologists sought to investigate and categorise non-European peoples. Colonial anthropologists such as John McLennan (1865) and Lewis H. Morgan (1877: 186-275) mapped and taxonomised marriage and family forms, which served to instruct colonial authorities on the legitimacy and desirability of non-European kinship structures. The categorisation of marriage and kinship forms was nearly always linked to temporalities of bourgeois European modernity. Eastern marriage forms could be windows into Europe's past (see Goody 1990) or, as with the native population of America, reveal the perverse and deviant 
social practices which could threaten to degenerate human 'progress' and 'development' (Rifkin 2015). Here the (un)gendered black slave represented a key series of absences that other peoples were categorised in relation to.

This was increasingly viewed in stark evolutionary terms. From the mid-nineteenth century, racial science and particularly colonial anthropology argued that marriage forms were suggestive of the evolutionary development of a society and its relative progress from 'simple' to 'complex' patterns (Benedict 1935; Mead 1964). It was argued that evolutionary patterns rested on an evolving form of heterosexuality:

From an initial state of 'promiscuous intercourse', there had arisen, in sequence, the 'Communal Family' (founded on the intermarriage of brothers and sisters); the 'Barbarian family'; ... the 'Patriarchal family' (founded on the 'marriage' of one man to several wives); and the 'Civilized Family'. (Hoad 2000: 140)

Deviant, perverse and decadent forms of intimacy - 'traditional' kinship, polygamy, promiscuity, same-sex intimacy - became aligned with premodern savagery. This was depicted as threatening the linear development of humanity towards its blossoming under the civilised family of European modernity (also see Benedict 1935: 189-191). To McLennan (1865: 8), particular bonds of legal intimacy could only be a product of a modernised society as 'marriage laws, agnatic relationship, and kingly government, belong, in the order of development, to recent times. The most primitive of societies, argued McLennan (1865: 9), were those that could only recognise blood relationship through the mother challenging or ignoring the template of European (and particularly British) patriarchal lineage. This temporalisation and spatialisation of family forms, from 'savage' to 'civilised', did not just replicate pre-existing racial categorisations but was also part of the ongoing process of colonial race-making. Here the 'discovery' of kinship forms that replicated European Christian marriage could be used as a sign of the potential for development of a society or its retardation (again see Amadiume 1987; Thomas 2007). 


\section{Family as development}

Hierarchical family taxonomies were central to the geopolitics of empire. In the same way that the absence of family in the enslaved was used to organise their dehumanisation, anthropologists focused on matrilineal, polygamous and tribal structures to reveal how African society remained 'undomesticated' and primitive (McLennan 1865: 10; Amadiume 1987). Goody (1990) demonstrates how 'Near Eastern marriage' was placed in this hierarchy, defined as it was by strong and often violently imposed communal ties. As with African 'bride pricing', Near Eastern marriage was viewed as a means of financial exchange and formative of an overzealous and 'cruel' patriarchal culture. Orientalist interpretations of Islamic law also pointed to the apparent feature of forced or intrafamily marriage where 'universal taboos' such as 'incest marriages' were actively promoted (Goody 1990: 321). The 'Asiatic marriage' form was recognised as a deeply religious and ancient series of rites. Certain religions and castes were labelled as emulating nascent forms of European domesticity such as Sikhs and Brahmins (Goody 1990: 17; on the role of religion and sexuality in colonial India see Nandy 1988 and Chatterjee 2010). Against this, 'traditional' practices such as polygamy, child marriage and purdah were viewed as a sign of backwards and uncivilised tendencies in other lower caste Hindu and Islamic communities (Gowans 2003).

As marriage was increasingly desecularised by liberal authorities throughout the twentieth century, what remained of these hierarchical taxonomies were distinctions between what Povinelli (2006) calls 'genealogical communities', where family forms were bound to tradition and ritual, and those forward-facing 'autonomous subjects' who practised marriage as a symbol of romantic love, choice and contractual exchange. This was used to explain the relative (under)development of societies globally and the resistance to progress that lay hidden in intimate relations (see chapter 3 for more on this).

The alignment of 'family' with a particular evolutionary geography meant that colonial projects either worked to contain deviant familial forms (through their rejection in law) or to promote normative 
alternatives. This was demonstrated in the promise of abolitionists and missionaries in Mauritius that black populations could alleviate their position or be redeemed through marriage and domesticity. Debates over how to domesticate colonial populations through forms of developmental violence thus faltered around this vision of heteronormative progress. To some administrators such as Henry Maine, progress would occur organically as 'marriages arranged by caste and kinship would give way to marriages based on individual contract' (Mody 2002: 228). However, at the beginning of the twentieth century more interventionist approaches became viewed as necessary. Acts such as the Concubine Act 1911 and the Child Marriage Restraint Act and Age of Marriage Act 1929 were developed to criminalise and punish non-normative intimacies across the British Empire. Other domesticating strategies were crafted in welfare and social work projects of home-making, such as in the construction of 'marriage schools' where Ugandan women were taught how to sustain patriarchal gender relations (see Mair 1944), or in the creation of model villages in India that were designed to teach 'backwards' populations proper forms of domestic governance and rituals of hygiene.

The shift towards the active promotion of marriage and family forms in the early twentieth century reflects broader imperial strategies of domestication and a push by British authorities to develop colonies as decolonial movements agitated for independence and were violently pacified. As with welfare programmes in Britain, the production of domesticated households, patriarchal monogamy and childrearing were viewed as central to economic development and producing desirable workers, as well as quelling revolutionary fervour (Owens 2015). Heterosexual, monogamous sex within marriage and the rearing of children were viewed as vital aspects of moral uplift and taking up wage labour.

In the Colonial Office's 1959 report on the future of Commonwealth development, H. L. Elvin was resolute that economic prosperity was tied to developing civilised family structures and suppressing 'traditional practices' such as polygamous marriage. 'These things will go', he argued, 
'just as certainly as Africa will move forward to participation in full modern life' (Elvin 1959: 12). Such ideas echoed the logic of the 1942 Moye Report on development in the Caribbean. The Colonial Office's welfare strategy proposed the creation of an entrepreneurial agricultural sector which relied on Caribbean women taking up patriarchal domesticity and rejecting the more extended kinship structures that sustained many communities.

In the push to develop and 'modernise' colonies, a key site for the promotion of (as well as hierarchisation of) family forms was also found in increasingly centralised border practices, especially those that pertained to the movement of racialised labour.

\section{Intimate borders}

Whilst technically all subjects of the British Crown had the right to travel across the Empire, as I described above this right was increasingly delimited by border practices from the 1870s, often in parallel with rising white nationalism in settler colonies. Immigration law increasingly restricted the movement of Asian labourers to settler colonies, but once contracted and registered, indentured labourers still held the right to travel with their families. This meant that at various points across imperial space border agents, medical inspectors, law makers, ship crews, ticketing agencies and so forth made decisions about whether subjects could move, or settle, based upon the proof of family ties to registered labourers and 'settled persons'. In doing so, this provided colonial states with the opportunity to monitor and shape what cultural forms of kinship and intimacies were legally and culturally recognisable as 'marriage' or 'family'. At the same time this created a site to make certain intimate relationships possible over others.

In South Africa the Immigration Regulation Act 1913 made provision to limit and regulate subjects at entry points such as major ports but also made provisions to detain labourers travelling without an official registration (i.e. a valid labour contract or official papers). Registered 
labourers and merchants could travel with their families. However, what complicated this right was the struggle over whether polygamous marriage could be included as 'family' (Mongia 2018). The normative idea of 'family' in South Africa was explicitly codified in the Immigration Regulation Act 1913 as Christian, monogamous, heterosexual marriage and included biological parentage of children under 16. And yet, imperial law upheld the right to polygamous marriage. What this produced was a complex network through which border agents in South Africa and other settler states tried to limit and deny the right of passage for Asian labourers and their kin on the basis of the suspicion that they were not 'real families' (see Shah 2012). Following the 1913 Act, officials in the Transvaal were given increased powers to inspect the papers of suspect aliens and take fingerprint and biographical records at transit points such as train stations (see Chamney 1915). Although family members were allowed to travel with registered labourers, colonial administrators were anxious about the true identities of subjects travelling and working under the guise of 'children' or 'spouse' status.

Communiques during the 1910s reveal the extent to which immigration officers, medical inspectors and port authorities were tasked with judging the validity of these embodied family claims (Chamney 1915; Horsfall 1915). Unaccompanied Indian youth were the target of particularly intense scrutiny. M. Chamney, the principal immigration officer in the Transvaal, recollects in a letter to the Colonial Office his experience of interrogating 'hindoo minors' crossing the province. They were, he recounts, well versed in performing the 'lies' needed to escape detention by claiming particular parentage or using communal ties to secure registration and documentation (Chamney 1915; also see MacDonald 2012). In another account, 'children' waiting to be interrogated by port police in Cape Town were deemed 'suspect' because of an inability to speak English and because they provided ambiguous claims about who their fathers were. In such contexts, administrators consistently stressed the logistical nightmare of the 'family' loophole and the problem of disproving parentage of 'Asiatic' children 'who often did not look to be related' (Chamney 1915), particularly where formal 
records of Indian marriage rites and parentage were not consistently available or documented.

In an early rendition of border inspections and the struggle over family immigration law that would follow, we can consider here how particular cultural imaginaries coalesced in the categorisation of who was a 'genuine' family, and in the bureaucratic process to categorise and authenticate 'suspicious' intimacies. The white colonial gaze was confounded by linguistic differences and apparent physiological characteristics of 'biological family members' (Immigration Regulation Act, SA 1913, Chapter 2, 4.1). It was similarly perplexed when confronted with intimate relationships that were not codified by state registration such as marriage and polygamous marriage rituals. Such doubt over the legitimacy of Hindu and Islamic marriage rites feed into other orientalist imaginaries of Indians as sneaky, disguised and possessing communal ties which confounded the policing of the colonial state (see Sleeman 1839). To officials, the complex kinship structures that they were asked to adjudicate on were indicative of a more general moral and cultural malaise. This reflected how 'the Indian community does not desire finality' - 'finality', that is, in the clear categorisation and appropriate parental and gendered relationship of bourgeois (white) domesticity (Chamney 1915: 12).

Border decisions over who could be family were shaped by what a family was supposed to look like, but they equally conditioned who could move with whom. As we see with the above cases, non-adherence to normative kinship meant exclusion from the rights of imperial citizenship and settlement based on family life. But equally, bordering shaped who could be familial through historical frames of intelligibility - in their affective relations, movement and behaviours, people could be judged to be familial or not.

Such heteronormative ordering was an inherently violent project. Negotiations over what 'family' could be were sites of disciplinary violence (including deportation, imprisonment, abandonment, separation of kinships and family members). This was not merely reflective of the fumbling of administrators and the absence of appropriate means of 
paper identity but part of micro, everyday practices through which questions over personhood were continually arranged by normative ideas of family. In the end it is only the corporeal intimacies privileged as white that could be offered sustenance, protection and public legitimately through imperial citizenship. It is significant here to note that whilst the imperial state temporally and formally granted polygamous marriages legal status across the Empire, this was short lived and was radically overturned by the British state in the 1960s with the increase of Asian subjects moving to the UK.

Whilst family taxonomies provided colonial administrators with knowledge of population development, this was always arranged, as I proposed above, around the absences of the figure of the black slave who was without family. This was always contrasted against the idealised patriarchal domesticity of white coupledom. Other intimacies were deemed to be 'imitations' or 'shams' which were stuck in time. Heteronormative family not only configured the colonised as living in a 'European past' but often as inhabiting a separate time from humanity proper (Agathangelou and Killian 2016: 8). Scrutinising these sham intimacies and the potential for developmental progress would be a task for border practices over the course of the twentieth and twenty-first centuries (see chapter 3 ). This happened as bordering was intensified in northern states, which were increasingly focused on the movement and settlement of people from colonies to the European metropoles. In the next section I turn to how the different bordering tactics of the British Empire 'came home' and were domesticated within the metropole and postcolonial Britain.

\section{Revolt(ing) intimacy and empire 'coming home'}

In June 1919 a string of violent mob attacks on black communities living in Liverpool became termed a 'race riot' (May and Cohen 1974). Over the course of the month, numerous clashes between white and black sailors took place across the English city. This unrest further 
extended into August when the police themselves went on strike and set forth a series of violent protests which were eventually quashed by the deployment of three army battalions, several naval destroyers and a battleship on the River Mersey. In the aftermath of the so-called race riot, commentators sought to place the event in the spiralling unrest that was growing across the British Empire, with the rise of pan-African consciousness, decolonial social movements and the Bolshevik revolution (May and Cohen 1974). The causes of this unrest were also put into a now common logic of colonial racism: the 'black peril' - the apparent threat that black men posed to white women in the port city. White men (both local and alien) were seen as defending, in the words of The Times newspaper, their race and the instinctive certainly that sexual relations between white women and coloured men revolts our very nature' (quoted in May and Cohen 1974: 114).

In a bid to suppress further violence and regain order, the police instituted a series of mass arrests and the detention of seven hundred black subjects 'for their own safety' (May and Cohen 1974: 114). The Superintending Officer of Liverpool's port then introduced special registration cards and fingerprinting of 'alien' seamen. In doing so, authorities appropriated technologies of criminalisation and identity capture that had been experimented with in colonial India and across settler plantain economies. As with previous restrictions on 'aliens' this did not legally affect British subjects. However, black sailors were frequently defined as 'alien seamen' by the local authorities until they could prove otherwise (a task that was nearly impossible, as carrying a passport was not a requirement of travel from colonies to Britain). Despite outcry against this policy by black community leaders, immigration orders increasingly became viewed as a useful device for suppressing racial disorder in the UK's port cities, and in turn disciplining black bodies. In the Aliens Order 1920, deportation of 'aliens' was formalised and streamlined, and then in the Special Restriction (Coloured Alien Seamen) Order 1925 specifically targeted people of colour for expulsion. Deportation of black British subjects again worked by proxy, as anyone suspected of being a 'coloured alien seaman' could be deported. 
Given the arbitrary nature of these powers, they were frequently used to police, harass and punish black communities living in port cities across Britain.

Colonial domestication was again at the heart of this encounter, as the bordering practices that had been honed across the British Empire found new uses in the metropole. Here the racialised distinctions that made up imperial citizenship were reformed as black and Asian subjects were deemed 'unworthy' of the right to settlement and movement. Internment, detention and deportation, tools that were experimented with across the Empire, were reasserted to both police and expel racialised communities within Britain in the name of white supremacy. In the face of decolonising movements and the unravelling of order in certain parts of the Empire, emergent immigration laws (alongside older modes of policing and social government) were increasingly viewed as vital to reassert the appropriate sentiments of white intimacy and racial segregation 'at home'. Whilst this was not the first time that bordering practices had targeted black and other racialised communities in the metropole (see Wemyss 2009), the Special Restriction Order set a precedent for immigration law that would intensify across the twentieth century and through formal decolonisation.

\section{Immigration and the colour line}

From 1905, centralised British immigration law drew upon border tactics and logics that had been experimented with across imperial space, in the formation of a 'national' border regime. Imperial in history and in orientation, immigration law began to focus on the cultivation of white Britishness - whilst remaining tied to wider claims of the imperial 'Anglo-Saxon' family. Whilst initially orientated towards the policing of 'aliens', particularly Jewish refugees arriving from Russia and Eastern Europe after the succession of pogroms in the 1890s, the state border regime began increasingly to focus on British subjects of colour. 
As colonial practices were turned further 'inwards' to refocus on Britain and racialised communities within the metropole, claims to family played a powerful role in this re-alignment. Debates over the limits of race relations, national identity, social and economic order, welfare and policing were played out in debates over appropriate forms of intimacy, sexuality and domesticity of people of colour. For instance, in the eugenics-inspired 'Report on an investigation into the colour problem in Liverpool and other ports' in 1930 the authors argued that 'black seamen were twice as likely to carry venereal diseases, and that mixed race or "half caste" children were more likely to be sickly" (EddoLodge 2017: 20). In the categorisation of 'English' or 'Negroid' children, the report drew on colonial ideas surrounding bloodline and inheritance as well as facial measurements from eugenics to warn against both the risk of 'colour' and 'racial mixing.'

Anxiety about the racial composition of Britain was configured in the scrutiny placed on colonised people arriving in the UK. Immigration management increasingly became a site to play out the protection of white patriarchal domesticity by restricting mobility based on race. This did not begin with the larger scale movements of people from the Caribbean and the Indian subcontinent, and the now famous arrival of HMT Empire Windrush to Britain in 1945 (see, for example, Wemyss 2009). However, bordering was certainly scaled up and intensified in post-war Britain. Family immigration law worked with other bordering mechanisms, such as policing, health, education and welfare, to establish a template for the type of intimate relations that could be tolerated within and that could move to Britain (see Jackson 2015: 161). In 1947 the British government, in a bid to consolidate imperial ambitions against decolonising movements, changed citizenship law so that any subject within a British territory was promised the right to move to, work, settle and claim full citizenship rights in the UK. ${ }^{4}$ The structure of various immigration laws from the 1960s onwards, and forwarded by all the main political parties, was to dismantle these rights until they were eventually overturned in 1981. Gurminder Bhambra (2017b) argues 
that this process was one of converting 'citizens' into 'migrants' (also see Karatani 2002).

As with the movement of racialised labour across the British Empire, bordering in the UK worked to support demands for an influx of a cheap and exploitable work force, at the same time as restrictions were increasingly imposed because of the fear of chaotic 'race relations' brought about by 'coloured immigration' (Hansen 2000). It is worth remembering that it was not movement per se in this period that led to the introduction of extensive immigration restrictions. For example, some two hundred thousand people settled in the UK from Southern Europe between 1945 and 1948, and this led to no overhaul of the immigration system (Bhambra 2017b). Such large-scale resettlement is almost entirely forgotten in dominant histories of immigration because it was predominantly white. Instead, it was the movement of those racialised as non-white that needed to be managed (Gilroy 1992).

From the 1960s, bordering practices fluctuated from facilitating the movement of family members of Commonwealth citizens, to delimiting the mobility of family members because of raised anxiety about the 'unfamilial' character of black and Asian communities (Webster 1998). Whilst patriarchal family structure was viewed as producing a compliant, orderly workforce and containing racial disorder (through the 'threat' that black and Asian men posed to white women), alternative kinship structures were viewed as the remnants of underdevelopment, 'primitive' culture and 'savagery' (Turner 2014).

The Immigration Act 1962, for instance, restricted Commonwealth citizens' right to move by making employment a mandatory requirement of entry into the UK. However, 'family members' were guaranteed special status and could reportedly move 'freely' (until this was ended in 1968). As I have already demonstrated above, evidencing who was family to claim the right to settle replayed distinctions over who was properly familial within imperial and evolutionary hierarchies. Debates in Parliament circulated around how Caribbean families could provide evidence of family connections because of the frequent absence of proper marriage or evidence of kinship (Hansard 1961). Fears that polygamous marriages 
would allow multiple partners and dependents into the country were equally recycled (see also Foreign Office 1933). In the 1962 legislation, 'dependent' family members were overtly classed as married wives and children (Home Office 1962: 7-8) or dependent elderly relatives, making the entry of husbands or male fiancés more difficult (a practice which would later be intensified in the now infamous 'primary purpose rule'; see chapter 3) (Smith and Marmo 2014). This essentially led to the outlawing of non-normative family structures from imperial/British citizenship.

Equally, border agents working at airports and ports were given discretionary powers to decide whether a person had a 'reasonable' family relationship to a settled person (Home Office 1962: 8). Replaying the restrictions placed across the British Empire, such strategies provided new tools for surveillance over the intimate relations of colonised subjects. These border practices also worked to produce certain types of family, that is by making heterosexual kinship and marriage a mandate of citizenship and settled rights.

\section{Citizenship, bloodline and inheritance}

Whilst family immigration law worked to surveil intimacies (a point I take up in more depth in chapter 3), citizenship was increasingly organised throughout the mid-twentieth century around the defence and promotion of the white 'Anglo-Saxon' family. This family had both a national (i.e. British, or more specifically English) and imperial white constituent (i.e. tied to settler states or 'dominions').

In order to dismantle the rights claims of Commonwealth citizens of colour, successive British governments from 1968 to 1980 pushed to define British citizenship in terms of biological inheritance. Firstly, in the 1968 and 1971 immigration acts, the right to abode was restricted to those who could prove a line of descent to a parent or grandparent born or naturalised in Britain. This was finally consolidated in the British Nationality Act 1981, which ended the (now much reduced) 
rights of Commonwealth citizens to residency. After 1981, British citizenship was defined by being born into citizenship through an ancestral connection to Britain (and not the Empire). Citizenship was thus actively reimagined as a structure of bloodline and kinship in line with key imperial claims about race. Whilst formally eviscerating the rights of millions of Commonwealth citizens, the Act preserved the connection of white subjects to British citizenship as they were more likely to be able to evidence an ancestral connection (i.e. to the 'Anglo-Saxon' family). The privileging of white mobility and the simultaneous containment of people racialised as non-white was managed through binding heterosexual family further into the codes of citizenship.

It is telling that after the Falklands War, Margaret Thatcher would in 1983 grant the Falkland Islanders 'special citizenship status'. She did this whilst recalling that they were of 'British stock' (Thatcher 1982). It is worth dwelling on the how the inheritance of whiteness or blackness worked in this setting. Thinking through this racial claim to 'British stock', we should consider that the British Nationality Act was more than a reorganisation of citizenship as 'national belonging'; it was the reimposition of an older patriarchal colour line which had sustained the British Empire. Just as inheritance worked to 'pass on' slave status, or encode people as white and 'free', reproduction was institutionalised as the site for the (non)transference of British citizenship and the organisation of inherited rights into the polity. Citizenship was legally bound to both the reproductive white family and the racial scientific fantasy of bloodline. Just as claims to family dispossessed colonised people of their personhood across the Empire (as undomesticated and 'deviant'), this worked to dispossess millions of former colonised people of their right to settlement in Britain.

As the British Nationality Act passed through Parliament in 1981, black protestors in London were actively railing against both police violence and the institutional racism of the British state in what became known as the Brixton Riots. Imogen Tyler (2010) argues that we should see a direct connection between the passing of the Act, which made Commonwealth subjects into second-class citizens, and revolts by black 
political activists taking place in the London borough (also see Andrews 2018). Just as immigration and citizenship law stripped people of their rights and managed racialised communities as 'internal others', the police functioned as an occupying colonial force to violently contain, suppress and punish resistance (Jackson 2015).

It is significant that in the aftermath of the Brixton Riots, the Scarman Report would eventually admit that the event revealed discriminatory policing tactics against black communities, for example in the use of colonial bordering tactics such as the 'sus' vagrancy laws to crush protests or in the mass incarcerations brought about by the authoritarian practices of Operation Swamp (Jackson 2015). However, Lord Scarman also laid the blame for the violence at the feet of the black community in Brixton. One of the causes of the riot, he argued, was the violent tendencies of black youth who grew up in 'single parent families' (Amos and Parmar 1984). Violence, ultimately, was a product of a lack of domestication - the key to this being (failed) black motherhood. Not only would citizenship now be inherited as a bloodline, but this faltered around the absence of black motherhood, a key factor in the inherited 'essence of slavery'. It is telling that as the British government re-institutionalised the racialised sexuality of the Empire into citizenship law that (failed) black motherhood would be presented as the site for the reproduction of social ills.

The British Nationality Act 1981 was one of many examples of how the logic and orientation of bordering practices of the British Empire became nationalised and brought more closely in line with the British nation state. Whilst still locked to an imperial mapping of the world, bordering practices increasingly focused on both policing communities of colour within Britain and restricting the possibility of movement into the country. We must consider this process as a set of acts of colonial duress - the adaption and intensification of Britain as imperial terrain, and a process of internal colonisation reaffirming the racialised governance that structured colonial administrations globally (also see Turner 2018). Whilst colonial rule was further intensified and bound to the policing of once-colonised or peripherised communities within 
Britain, the cultural and social landscape of Britain worked to deny such linkages, either through a disavowal of the Empire (as 'past wrongs'), or a nostalgic harking back to the lost privileges of whiteness found in more explicit appeals to white nationalism. In such a context, as I shall argue over the next few chapters, appeals to family continued to work both to stratify people as modern or backwards, domesticated or undomesticated, and to hide the colonial and racialised coordinates of such work.

\section{Conclusion}

This chapter has demonstrated some of the intimate historical connections between family and bordering that circulated from British colonies to the metropole. 'Family' emerged as a key technology in sustaining and fostering colonial projects and in the nineteenth century became increasing bound up with the regulation of movement. Family worked here as a governmental mechanism to shore up whiteness, but equally it was central to the domestication, surveillance and suppression of colonised people and the regulation of their mobility. Claims to family, as I have previously proposed, ultimately structured claims to humanity.

I have argued that bordering, as it expanded the regulation of movement in the nineteenth century, rather than being a nationalistic project was in fact imperial in orientation. Bordering was both an imperial and colonial project. The regulation of movement was central to colonial states' bid for order (as illustrated in India and Jamaica). Bordering functioned to facilitate and control the mobility of slaves, mobile people and indentured labourers through the shifting dictates of imperial capitalism and racialised sexuality. Bordering here must be seen as more disparate than state-sanctioned immigration law or the management of 'migrants' or 'aliens'. It was forged in the management of escaped slaves, rebels, criminals, nomadic communities, prostitutes, indentured labourers - some who had legal status to travel, others who did not. Equally, bordering was practised by multiple social authorities, not only 
the imperial, settler or colonial state, from shipping companies, medics, labour camp inspectors, to missionaries, police and plantation masters.

The regulation of mobility across the British Empire was orientated towards the management of the global colour line by discovering and controlling people 'out of place'. This was institutionalised in the late nineteenth century by settler states in nascent immigration law, but imperial authorities colluded and supported such bordering (such as in the 1875 Indian Ports Act). Whilst concerned with containing, identifying and expelling '(un)productive,' 'dangerous' or 'deviant' subjects, bordering practices were frequently energised by appeals to heteronormative family, a key lynchpin of (settler) colonial order.

Fleshing out the approach to family and domestication I began in the last chapter, I have demonstrated that family - or more specifically the claim to a heteronormative, monogamous (white) nuclear family - energised colonial projects and, with this, bordering practices. Family took on multiple roles in empire-making; it functioned to dehumanise and dispossess. Personhood was arranged through bloodline, such as in the case of slave law. but people could also be judged as more or less human based on where they fell within family taxonomies. That is, whether they emulated Christian marriage and bourgeois domesticity. Family could also be developmental. Populations could be 'brought into' civilisation and be 'developed' by the facilitation of familial and patriarchal domesticity. Family could be control. Claims that the 'true family' was European and white led to the management of interracial intimacy, just as suspicious intimacies (such as polygamous marriage and extended kinship structures) were intervened in, suppressed and expelled by colonial states.

Throughout these processes, 'family' became key to how mobility was perceived and regulated. Bordering and then borders (immigration law) worked to protect and defend (white) family life, either to foster or protect it (such as the example of the masculine/sexualised threat of black sailors in Liverpool); borders worked to delimit and intervene in intimacies viewed as unfamilial (polygamous kinship, unmarried or same-sex couples); borders worked to shape and produce familial 
relationships (such as promoting the movement of the wives of black and Asian Commonwealth citizens). By being attuned to different archives of bordering, I have illustrated how various forms of colonial knowledge and practice informed what we know as 'family' and its absences. Different claims to family were not merely a set of contingent and 'culturally located' ideas about kinship, but instead a site of racialised power where struggles over personhood, life and death, inclusion and abandonment were played out.

By ending with a focus on British immigration law, I have emphasised how colonial rule worked across metroimperial space but was contingent upon local struggles. In examining the codification of citizenship and immigration law in the UK, I have argued that this was a reinscription and adaption of imperial and colonial government to the particular demands of white supremacy and familial order. From the 1920s, centralised immigration became a key site for the ongoing domestication of colonised peoples. Immigration law and the bordering this entailed was orientated towards delimiting the right to settlement of Commonwealth citizens of colour. And equally, facilitating the mobility of white subjects of the 'Anglo-Saxon' family (often from settler states). Furthermore, bordering practices, often bound up with but not exclusively driven by immigration law, were frequently drawn from experiments of colonial rule. Consider, here how practices of detention and deportation were tested and honed across the British Empire, such as in the control of indentured labourers, and then circulated back 'home' to manage growing racialised communities in the mid-twentieth century. Following the role of bordering and family across the Empire, immigration law became a key site for the rehearsal, reimagining and intervention into non-normative intimacies in the UK. In doing so it provided a means of controlling the movement of colonised subjects but also a means of producing and shaping what family could be.

As I will go on to explore in the next three chapters, the ongoing border regime in the UK continues to be forged through, and equally to reinvent, colonial rule as an intimate spectacle. This means recognising that the reasons why people move are intimately bound to empire, in 
the same way that practices that regulate movement equally work along and resuscitate 'imperial grooves' (de Noronha 2018).

\section{Notes}

1 This chapter was based on archival work undertaken from 2016 to 2017 at the National Archives, Kew; the British Library, London; and the Bristol Archives.

2 I talk less about the role of convicts in the regulation of mobility in this chapter. The creation of penal colonies provides another fascinating history of movement, often arranged around ideas of failed whiteness and the regulation of 'internal others' within Britain, orientated as this was towards projects of settler colonialism (such as in Australia). For more on this see Walters (2002), Wolfe (2006) and even Turner (2016).

3 The British Crown Colony of Mauritius included the contemporary territory of the Republic of Mauritius, Rodrigues, the outer islands of Agaléga, St. Brandon, Chagos Archipelago and Seychelles.

4 Devising the newly titled Citizen of the UK and Commonwealth. 